\title{
EQUALITY, DEMOCRACY, AND CONSTITUTION: WE THE PEOPLE IN COURT
}

\section{RONALD DWORKIN*}

Commentators have seen the disabling provisions found in the American and Canadian constitutions as undemocratic because they restrict majority powers. Building upon the work of John Hart Ely, this paper puts forward a conception of democracy which nourishes both collective responsibility and individual judgment. The author distinguishes between "statistical" and "communal " conceptions of democracy. Traditional theories, such as Ely's, have relied on the statistical notion which conceives of individuals in a democracy acting each on their own. In the communal conception, decisions are made by the "people" acting as a distinct and collective unit of responsibility. The author then elaborates on the communal conception by identifying two variations of it, "integrated" and "monolithic"'forms of collective action. In the latter, both the unit of responsibility and the unit of judgment are collective, while in the former the unit of judgment resides in the individual. If democracy is understood in the integrated communal sense, then many of the disabling provisions in the American and Canadian constitutions can be seen to enhance democracy rather than contradict it.

\begin{abstract}
Certains commentateurs estiment que les dispositions abrogatoires des constitutions américaine et canadienne sont antidémocratiques en ce qu'elles limitent les pouvoirs de la majorité. En invoquant les travaux de John Hart Ely, cet article propose une conception de la démocratie qui entretient à la fois la notion de responsabilité collective et celle de jugement individuel. L'auteur fait la distinction entre les notions "statistique" et "collective" de la démocratie. Les théories traditionnelles semblables d celles d'Ely, reposent sur la notion statistique selon laquelle, dans une démocratie, chaque individu agit indépendamment. D'après la conception collecrive, les décisions sont prises par le "peuple" en tant qu'unité responsable distincte et collective. L'auteur développe cette notion plus avant pour en proposer deux variantes - Les formes "intégrée" et "monolithique" d'action collective. Dans la seconde forme, l'unite de responsabilité et celle de jugement sont toutes deux collectives alors que, pour la première, l'unité de jugement réside chez l'individu. Si l'on conçoit la démocratie au sens collectif intégré, bon nombre de dispositions abrogatoires contenues dans les constitutions américaine et canadienne seront perçues comme favorables à la démocratie plutôt que jouant contre elle.
\end{abstract}

\section{TABLE OF CONTENTS}

I. THE PROBLEM $\ldots \ldots \ldots \ldots \ldots \ldots \ldots \ldots \ldots \ldots \ldots \ldots, 325$

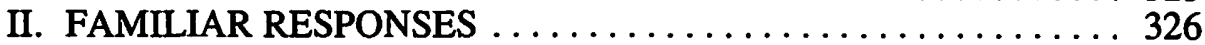

III. CONCEPTIONS OF DEMOCRACY $\ldots \ldots \ldots \ldots \ldots \ldots \ldots \ldots 328$

IV. EQUALITY OF POWER $\ldots \ldots \ldots \ldots \ldots \ldots \ldots \ldots \ldots \ldots \ldots 331$

A. VERTICAL AND HISTORICAL DIMENSIONS $\ldots \ldots \ldots \ldots 332$

B. IMPACT AND INFLUENCE $\ldots \ldots \ldots \ldots \ldots \ldots \ldots \ldots \ldots, \ldots \ldots$

C. SHOULD INFLUENCE BE EQUAL? $\ldots \ldots \ldots \ldots \ldots \ldots \ldots, 333$

V. COMMUNAL COLLECTIVE ACTION $\ldots \ldots \ldots \ldots \ldots \ldots \ldots, 335$

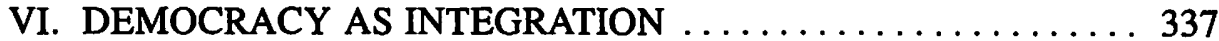

A. THE PRINCIPLE OF PARTICIPATION $\ldots \ldots \ldots \ldots \ldots \ldots . \ldots 337$

B. THE PRINCIPLE OF STAKE ............... 339

C. THE PRINCIPLE OF INDEPENDENCE $\ldots \ldots \ldots \ldots \ldots \ldots 340$

VII. COMMUNITY AND CONSTITUTION $\ldots \ldots \ldots \ldots \ldots \ldots \ldots, 342$

A. THE PLAIN PROVISIONS $\ldots \ldots \ldots \ldots \ldots \ldots \ldots \ldots \ldots 343$

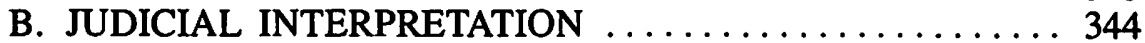

* Professor of Jurisprudence, Oxford University and Professor of Law, New York University. A version of this paper was delivered as the inaugural McDonald Constitutional Lecture, sponsored by the Centre for Constitutional Studies, and delivered at the Law Centre, University of Alberta on March 13, 1989. 


\section{THE PROBLEM}

I shall talk about the snake in the garden, the nasty problem supposed to be at the center of constitutional law.' Is judicial review undemocratic? In Canada and in America - and at an increasing rate throughout the democratic world - judges declare laws unconstitutional that were enacted by lawmakers who were elected by a majority or plurality of the voters. Judges declare these laws unconstitutional even though the constitutional requirements they are said to violate are not specific and detailed or self-enforcing but are written in abstract language about whose actual meaning reasonable and reasonably trained people violently disagree.

It is no wonder that this form of judicial review is widely thought undemocratic. Democracy means rule by the people and this seems to be rule by the judges instead. In fact there are two respects in which a constitution might seem undemocratic, and that quick summary catches only one of them. Judges on the highest courts are appointed rather than elected, and barring extraordinary misconduct they serve for life. So a system that gives such judges great political power seems offensive to the principle that in a democracy officials are chosen by and answerable to the people. But that is not the whole story. We do not think it seriously undemocratic that other powerful officials are not elected. Secretaries of State or Defense or Treasury are not elected, and they can do more damage in a week than any single judge can in his or her judicial lifetime. American Presidents are elected, of course. But once they are in place they can wield their promethian powers almost unaccountable for at least four years, in which time they can easily destroy the world.

The real threat a constitution poses to democracy is deeper, and has nothing to do with the fact that judges are not elected. We know that in a complex, representative democracy the majority's will cannot always govern. But for the most part we accept that in any democracy the majority should govern; we think that though institutional structures that insulate officials from popular opinion are necessary in practice, they are undesirable in principle. But when constitutions declare limits on the majority's power, this democratic assumption is displaced: decisions are not supposed to reflect the will of the majority then. Every official swears loyalty to the constitution, and therefore has a responsibility to defy popular will when the constitution's guarantees are in play. But that responsibility is most vivid when judges are asked to test legislation that has already been enacted, and so tacitly certified as constitutional, by other officials. Judges then claim a right and a duty to stand in the way of what the majority's representatives think proper and in the interests of the community as a whole.

So judicial review is not just undemocratic exceptionally or when it is working badly, as other institutions are, but undemocratic steadily and when it is working well. Or so most commentators and scholars think. Many of them, though not all, believe that judicial review is a just and wise institution; many, though not all, think America and now Canada are better political communities just because they are

1. This paper is one of a series of essays I have written on the idea of equality. See Dworkin, "What is Equality? Part 1: Equality of Welfare" (1981) 30 Phil. \& Pub. Affairs 185; Dworkin, "What is Equality? Part 2: Equality of Resources" (1981) 10 Phil. \& Pub. Affairs 263; Dworkin, "What is Equality? Part 3: The Place of Liberty" (1987) 73 Iowa Law Review 1; Dworkin, "What is Equality? Part 4: Political Equality" (1987) 22 Univ. of San Fran. L. Rev. 1; Dworkin, "Liberal Community" (1989) 77 Cal. L. Rev. 479; Dworkin, "Foundations of Liberal Equality", 1989 Tanner Foundation Lectures forthcoming from University of Utah Press. 
not perfect democracies. But almost everyone concedes that judicial review compromises democratic principles. Lawyers who think this a very serious fault in their constitution are anxious that the constitution be interpreted narrowly, to minimize that flaw. Those who think the fault less serious, and so support a more generous interpretation, nevertheless agree that it is a fault; they support the constitution, on balance, in spite of that weakness.

It is important to notice what will seem obvious, however: no one could sensibly think that every section of a typical national constitution is necessarily undemocratic. Most contemporary written constitutions have both expressly structural and expressly disabling provisions. The plainly structural provisions are those that construct and define powers, instruments, and agencies of government: they provide when elections take place and who may vote and for how long various elected officials serve. These provisions may of course be undemocratic: they might limit suffrage to only a small part of the population, for example. But structural provisions are not undemocratic just because they cannot be changed by mere majority vote. If the institutions the structural provisions create are democratic ones - if they provide for near universal suffrage among competent adults and for officials who are reasonably responsible to the electorate - then it enhances democracy that a contemporary majority cannot change the constitution whenever it wishes to solidify its power and prevent different majorities from forming in the future.

The disabling provisions are of course a different matter, because these set limits to the power a majority has under the explicit structural arrangements. In the American Constitution, the disabling provisions are mainly set out in the Bill of Rights: the first ten amendments and those added after the American Civil War. These provisions, among other things, forbid either the national or any state government from abridging freedom of speech or taking life or liberty or property without due process of law or denying anyone the equal protection of the law, or changing certain established criminal procedures, and so forth. It is these disabling provisions that lawyers have in mind when they claim or concede that the Constitution is inherently undemocratic. They assume that the structural provisions create a genuine democracy, and therefore that any limit the Constitution places on the power of a majority of electors to do what they think right or best is undemocratic.

\section{FAMILIAR RESPONSES}

American constitutional lawyers have responded to what they believe to be the problem of democracy in a variety of ways we might now notice. One group, conceding that the Constitution is undemocratic, replies defiantly. They say that democracy isn't everything, and that protecting individual rights when these are threatened is more important than giving effect to the majority's will. They want the disabling provisions of the Constitution interpreted in that generous spirit; they invite the Supreme Court to give full and unembarrassed force to the moral principles they believe should hedge democracy. I have some sympathy with this reaction to the problem. But it encounters two familiar objections it must answer. First, we believe that only in a democracy does government treat people as equals. How can it then be justified to compromise democracy on any occasion? Second, democracy is not just one right among others, but a theory about how a community should decide what other rights to respect. So if we prefer a Supreme Court 
Justice's opinions about what counts as free speech and how free speech should be protected to the opinions of a democratic majority, we are contradicting our most basic assumptions about how a community's values ought to be chosen. The true contrast, we might say, is not between democracy and other values, but between democratic and elitist methods of deciding what other values to recognize.

The other familiar responses I shall describe all accept that democracy must be paramount, and that a constitutional system of disabilities should therefore be interpreted and applied so as to ameliorate its anti-democratic character as far as possible. The historicist response insists that this can best be done by allowing constitutional provisions to disable majorities only to the degree actually and concretely intended by past majorities - the super-majorities who enacted the provisions in the first place. So historicists study records of constitutional conventions and debates to discover evidence of what the statesmen of long ago, deemed to be reflecting the views of the people they represented, thought they were preventing future majorities from doing. After all, even though disabling provisions may prevent contemporary majorities from doing what they wish, the assault on democratic values is not so great if that disability is imposed by an earlier, larger majority rather than by judges elected by and representing no one.

The historicist response produces an extremely conservative, even antiquated, constitution which favors established political and economic arrangements. Indeed, that is undoubtedly part of its appeal for many people, and helps to explain why it has continued to be influential in spite of its almost self-evident philosophical inadequacies and confusions. ${ }^{2}$ In the United States, at least, historicism is on a collision course with itself, however, because the historical evidence is impressive that the founding statesmen did not intend their own views on matters of political morality to be decisive in interpreting the Constitution. They intended the document to be interpreted in accordance with the soundest understanding of political morality, not just the understanding they themselves had reached when they wrote it.

Historicism should be distinguished from a quite different response, passivism, which also produces constitutional interpretations congenial to the status quo. Passivism rescues democracy from constitutional constraint by insisting on interpretations that, so far as possible, read'the disabling provisions out of the Constitution altogether by supposing them to give the majority power to do anything not patently irrational. The great American judge, Learned Hand, came as close to a pure view of passivism as anyone has: it led him to doubt the soundness even of the Supreme Court's most famous decision: Brown v. Board of Education, ${ }^{3}$ which declared that majority-imposed racial segregation in public schools offends the Constitution's guaranty of equal protection of the law. ${ }^{4}$ Other famous lawyers and judges, including Justice Felix Frankfurter ${ }^{5}$ and Professor Alexander Bickel, ${ }^{6}$ endorsed strong though less uncompromising versions of the view. Passivism

2. See Dworkin, Law's Empire (Cambridge, Mass: The Belknap Press of Harvard University, 1986) Chapter 10.

3. (1954), 347 U.S. 483.

4. See Hand, The Bill of Rights (Cambridge, Mass.: Harvard University Press, 1958) at 54-5.

5. See, for example, Mr. Justice Frankfurter's concurring opinion in American Federation of Labor v. American Sash \& Door Co. (1948), 335 U.S. 538 at 542ff.

6. See, for example, Bickel, The Least Dangerous Branch, 2nd ed. (New Haven \& London: Yale University Press, 1986) at 237-39. 
suffers from many jurisprudential defects, however, and its basic strategy, which is to try to read the disabling provisions as if they did not exist, is difficult to reconcile with the idea that the Constitution is part of a community's law.

The most interesting response to the problem of democracy, however, is the discriminating approach presented in its most elegant form by John Hart Ely. ${ }^{7}$ Ely pointed out that some constitutional provisions that are expressly disabling are also, understood functionally, structural: that these disabling provisions so far from compromising democracy are necessary to create it. Consider, for example, the common constitutional constraint that forbids parliaments from abridging free speech. Since democratic elections demonstrate the will of the people only when the public is fully informed, preventing officials from censoring speech protects rather than subverts democracy, even when the majority wants the censorship. So a constitutional right of free speech counts as functionally structural as well as disabling in our catalogue.

Ely applied the same analysis to other expressly disabling constitutional provisions. He said that the requirement that the majority not discriminate on racial grounds by segregating public schools, for example, improves rather than impairs democracy because political power is not equal when systematic discrimination and lack of education cheats one group of the political influence and self-awareness other groups have. But he tried to draw a fairly sharp line between those disabling provisions that could sensibly be regarded as functionally structural in that way and those that could not. It would not follow from his view, he said, that a constitutional rule forbidding the majority to declare homosexual acts or abortion criminal would be democratic, for example. That constitutional constraint is not necessary to insure that homosexuals or women who want abortions have the same political power as other people; if they lose in a political battle it is not because they are uneducated or have less voting power, one by one, than their opponents. It is because their views are too unpopular and their numbers are too few to win in a fair electoral fight, and that is what democracy is about. ${ }^{8}$

So Ely's approach, at least in his view, would not justify an expansive interpretation of the very abstract clauses of the American constitution. Indeed it does not rescue even some of the plain and direct clauses of that Constitution from the charge that they are undemocratic. The First Amendment's guaranty of free exercise of religion, and its provision disabling majorities from establishing a particular church, do not seem functionally structural. Nor do the clauses of the Bill of Rights that regulate criminal process and procedure or deny the majority the power to impose punishments that are cruel and unusual. So Ely's rescue of democracy from the Constitution is only, as he concedes, a partial success.

\section{CONCEPTIONS OF DEMOCRACY}

I shall propose a different response. It challenges the assumption these familiar responses share, that the problem of democracy is genuine and intractable. I believe

7. John Hart Ely, Democracy and Distrust: A Theory of Judicial Review (Cambridge, Mass.: Harvard University Press, 1986), c. 4 \& 5.

8. John Hart Ely, "The Wages of Crying Wolf: A Comment on Roe v. Wade" (1973) 82 Yale L.J. 920 at 923. 
the problem has been misunderstood and exaggerated because constitutional lawyers have concentrated too much on what the Constitution does and says, and how it should be interpreted, and not enough on what democracy really is. I begin with a benign but important observation: that democracy, like almost any other form of government, involves collective action. I mean only that in describing any complex form of government we must recognize units of action in which the actor is some group rather than any individual on his or her own. We say that in a democracy government is by the people. We mean that the people collectively do things - elect leaders, for example - that no individual does or can do alone.

There are two kinds of collective action, however - statistical and communal - and our conception of democracy will turn on which kind of collective action we take democratic government to require. Collective action is statistical when what the group does is only a matter of some function, rough or specific, of what the individual members of the group do on their own, that is, with no sense of doing something as a group. We might say: the Canadian people want a more aggressive and interventionist economic policy. We describe a kind of collective action: no one Canadian can act in such a way that he has made it true that the Canadian people think anything in particular. But the reference to the Canadian people is nevertheless only and simply a figure of speech: we do not think there really is a super-person cartoon figure, called the Canadian People, which has opinions of its own. Our remark only makes a rough statistical judgment of some sort about what (say) most Canadians think, or what most Canadians who think about the subject think, or something of that sort. Or we might say that yesterday the foreign exchange market drove up the price of the yen. Once again, we are describing collective action: only a large group of bankers and dealers can affect the foreign currency market in any substantial way. But once again our reference to a collective entity, the currency market, is not intended to point to any actual entity. We could, without in any way changing the meaning of what we say, make an overtly statistical claim instead: that the combined effects of the very large number of individual currency transactions was responsible for the higher price of the yen at the latest trade.

Collective action is communal, on the other hand, when it cannot be reduced just to some statistical function of individual action, because it is collective in the deeper sense that does require individuals to assume the existence of the group as a separate entity or phenomenon. The familiar but very powerful example of collective guilt provides a good example. Germans feel responsible for what Germany did, not just for what other Germans did; their sense of responsibility assumes that they are themselves connected to the Nazi terror in some way, that they belong to the nation that committed those crimes. I borrow and adapt another example from John Rawls. An orchestra can play a symphony, though no single musician can, but this is not a case of statistical collective action because it is essential to an orchestral performance not just that a specified function of musicians each plays some appropriate score, but that the musicians play as an orchestra, each intending to make a contribution to the performance of the group, and not just as isolated individual recitations. 9

The distinction between statistical and communal action allows us two different readings of the platitude that democracy involves collective action, two different 
readings of Lincoln's promise that democracy is government of the people and by the people and for the people. The first is a statistical reading of those ideas: that in a democracy political decisions are made in accordance with some function of the votes or decisions or wishes of the individual citizens one by one. On this reading democracy is different from other forms of government because in a democracy the function in play is majoritarian, or at least plurality, whereas in other forms of government different statistical functions are specified. The second is a communal reading: that in a democracy political decisions are taken by a distinct entity - the people as such - rather than any set of individuals one by one. That formulation is intended to remind you of Rousseau's general will, which I am inclined to understand as pointing to a communal rather than statistical conception of democracy.

Our response to the supposed conflict between democracy and a constitution will depend on which conception of democracy we accept, because the two conceptions draw the line differently between functionally structural and disabling provisions. On the statistical reading, structural provisions are mainly limited to those that are expressly structural - those that define who may vote, how members of parliament or congress are elected, what proportion of them it takes to enact legislation, and so forth. They may also include, following. Ely, certain disabling provisions necessary so that the expressly structural provisions can in fact achieve some equality of political power, like provisions protecting,freedom of speech and the press. But on the communal conception of democracy structural provisions need not be limited to those matters of procedure and organization. Further reflection might show, for example, that communal collective action is possible only if the members of the community share certain ideals; if so, the maintenance of those ideals through constraints on majority decision would itself be a matter of structuring democracy rather than qualifying or undermining it.

I expect that only the statistical reading now seems plausible or acceptable. Most think that the communal reading is at best a matter of Hegelian mystification, and at worst an invitation to totalitarian oppression.justified on the ground that the state is more important than the individual. I understand these fears and believe that philosophers are in part responsible for them, by failing to identify the important features of familiar kinds of collective action, like that of an orchestra for example, which are neither mysterious or threatening. Rousseau illustrates both the appeal of a better account of collective political action, and the confusion, into which he fell, in neglecting the distinction between what I shall call integrated communal collective action, which insists on the importance of the individual, and monolithic communal collective action, which denies it.

Most will have gathered by now that I shall try to defend the idea that the best account of democracy, for us, is given by the communal conception of collective action in its integrated rather than monolithic form. I have two reasons. First, the communal account is, I believe, more attractive than the statistical as a matter of political morality. Second, the communal account offers a better interpretation of the Canadian and American political communities, which include both democracy and constitutional constraints on majority will. Since the second of these claims in part depends on the first, however, I shall concentrate on the first in this essay, and I shall begin my argument by pointing out severe internal defects and inadequacies in the popular statistical reading of democracy. 


\section{EQUALITY OF POWER}

If democracy is a matter of political decisions representing some function of the individual decisions of members of the community, then this must be, as I said, a majoritarian function, or at least some function that does not allow that a political decision might be taken even though it commands less support among the electorate than a different decision would. ${ }^{10}$ It is that feature of the statistical conception that seems so obviously incompatible with most constitutional constraints on majority will. We must therefore ask what political value a statistical conception of democracy, interpreted as requiring a majoritarian function, serves. Why should we want a form of government in which collective decisions are all and only those that are supported by most people?

We should notice, but only to set aside, an epistemological answer to that question: that the majority is more likely to be right about which political decision the community should take than any other group is. That argument might very well be persuasive, at least in principle, about preference-sensitive political decisions: when the character and distribution of people's preferences in part determines which decision is the right one. "If the question arises whether the community should use designated funds to build a baseball stadium or an ice hockey rink, and we believe that decision ought to depend on which would be used more, a majoritarian political process seems the best way to discover the answer. But we have no general reason to think that the majority is more likely to be right than any other group about preference-insensitive issues, that is, when facts about the mix of preferences or opinions are substantively irrelevant. The fact that a majority of citizens approves capital punishment, for example, is in itself no argument that capital punishment is right. Since the question whether individuals have moral rights the majority should respect is plainly preference-insensitive - it would be absurd to suppose that individual citizens have these rights only if the majority thinks they do - the epistemological argument cannot justify the claim that the statistical conception of democracy is the right one.

Any plausible general justification of statistical democracy must be based on fairness and equality, in other words, not on the soundness of the answers a majority is likely to reach. Consider the following argument. Political equality - treating people as equals in the distribution of political power - means making people equal in their political power, and that can be achieved only by statistical majority rule. If this argument is sound, then one of the most fundamental political ideals, that a political organization must treat its members as equals, has a dilemma at its core. One part of equality - the input, procedural part - recommends a political system in which a majority is free to deprive minorities of the other part of what equality requires, which is an equal stake as well as an equal part in government. So the question whether treating people as equals does mean making political power equal is

10. I prescind, throughout this essay, from the celebrated difficulties in a statistical conception of a democracy stemming from Arrow's impossibility theorem, which are technical difficulties rarely of practical importance. I concentrate on defects in the statistical conception which show it to be undesirable rather than simply unattainable in full.

11. I explain the difference between preference-sensitive and preference-insensitive political decisions, and offer further examples, in a recent article, part of which I summarize in this section. See Dworkin, "What is Equality? Pan 4: Political Equality" (1987) 22 Univ. of San Fran. L. Rev. 1. I also draw, in this section, on an article on equality I prepared for the Italian Encyclopedia. 
a question of general importance for political philosophy. We should begin trying to answer it by asking what equality of political power really is. In fact equality of power admits of different interpretations or readings, and separating these is essential to understanding why they are all misconceived.

\section{A. VERTICAL AND HORIZONTAL DIMENSIONS}

How is political power to be measured? Under what circumstances is it equal? Any adequate answer must compare political power along two dimensions: not only horizontally, by comparing the power of different private citizens or groups of citizens, but also vertically, by comparing the power of private citizens with that of individual officials. If political equality is a matter of equal political power, both dimensions must figure in the accounting. Horizontal equality of power is hardly enough to provide anything we would recognize as a genuine democracy. In totalitarian dictatorships private citizens have equal political power: none. Cynical pretend-democracies with a single political party are usually scrupulous in providing each citizen with one and only one vote for that party. So the vertical dimension must come into play.

It seems incredible, however, that any genuine vertical equality of power could exist in representative democracies like Canada or the United States. How could American political structures and practices be revised, for example, short of destroying representative government altogether, so as to give every American citizen of voting age the same power over national affairs as a junior congressman, let alone as the President? So a conception of political equality that demands equality of political power might seem caught in a dilemma at the start. If it insists on horizontal equality only, equality among the governed, its most stringent requirements might be satisfied by plainly undemocratic tyrannies. If it demands vertical equality as well, then it is wholly unrealistic.

\section{B. IMPACT AND INFLUENCE}

We must bear that threatened dilemma in mind when we consider what equality of power might mean. We should distinguish two interpretations: equality of impact and equality of influence. The intuitive difference is this: someone's impact in politics is the difference he can make, just on his own, by voting for or choosing one decision rather than another. Someone's influence, on the other hand, is the difference he can make not just on his own but also by leading or inducing others to believe or vote or choose as he does.

The distinction between political impact and political influence suggests an escape from the dilemma I described. Obviously, vertical equality of political power is impossible if that means equality of political impact. A representative structure is necessarily one in which impact is vertically sharply different. But it does make sense to call for vertical equality, as an ideal, if the equality in question is equality of influence. We can even describe a fully representational system in which equality of influence holds, at least to the degree of precision to which it can be measured anyway. Suppose that officials accept that they have a duty to vote as a majority of those they represent wish them to vote. Suppose that elections are held sufficiently frequently, communication between officials and constituents is good 
enough, and recall mechanisms sufficiently efficient and inexpensive, so that officials do in fact hold to that duty. In those circumstances rough vertical equality of influence is realized. Since Senator $X$ will vote for tax reduction when but only when he believes that a majority of his constituents favor it, the information that he himself would prefer a reduction does not increase the subjective probability that he will vote for it any more than the information that any other of his constituents would prefer it increases that probability.

From the horizontal perspective, too, it would be implausible to understand equality of power as equality of impact, but now for the opposite reason. Equality of impact is not too demanding a goal but one not demanding enough. Equal impact does require that each competent citizen have a vote and the same vote, and it also requires one-person-one-vote districting. But it does nothing to justify a central assumption we make about democracy, which is that democracy requires not only widespread suffrage but freedom of speech and association, and other political rights and liberties, as well. My impact in politics is no less than yours when censorship denies me the right to present my views to the public but allows you to do so. Or when you are rich enough to control a newspaper but I am too poor to buy even one copy. We need to reach beyond the idea of equal impact to the idea of equal influence and to begin to explain why censoring the views of some denies equality of political power.

\section{SHOULD INFLUENCE BE EQUAL?}

But is equality of influence really an attractive ideal? Would we not hesitate to improve vertical equality of influence in the way in which we just saw this to be possible: by insisting that officials always act in whatever way a majority of their constituents wished, and adopting electoral devices that would punish those who do not? Do we want to come even as close as we can to making sure of their obedience? Do we not rather want our officials to lead rather than follow our views, at least on preference-insensitive issues?

Equality of influence on the horizontal dimension may seem a much more attractive ideal than it does on the vertical dimension, however. But that appearance is deceptive. The main appeal of horizontal equality of influence lies in the conviction that it is unfair that some private citizens have much more influence in politics than others just because they are much richer. But we can explain that intuition in two ways. We can, indeed, explain it as resting on the assumption that any great lapse from equality of influence among private citizens is a serious lapse in political equality. Or we can explain it in a way that does not appeal to equality of influence, as a general ideal, at all. We can say, for example, that it is unjust that some people have as much money as a Rockefeller because that violates the distributive principles of equality, and then add that the disproportionate political influence their wealth gives them is a particularly deplorable consequence of the injustice because it allows them, among other things, to perpetuate and multiply their other unfair advantages.

These two ways of objecting to a Rockefeller's political influence are, of course, very different. The first is insensitive to the source of his disproportionate influence; it supposes that aggregate influence, from all sources, must be equal. The second makes no assumptions about aggregate influence; it condemns a Rockefeller's 
influence only because of the particular source of that influence. We can contrast the two objections by imagining a world in which the first would hold but the second would not. Suppose the distributional goals of economic equality were met reasonably well, but some people still had more influence in politics than others. They might have more influence for a variety of reasons, but I shall assume reasons unobjectionable in themselves, because we are considering whether we should object to unequal influence as such. They might have decided to spend more of their initially equal wealth on political campaigns, for example, than other people have. Or they might have invested more in study and training which made other people more likely to consult them or listen to their advice. Or they might have led lives of such conspicuous achievement or virtue that others trust them more, or are more ready to follow them. The first form of objection to a Rockefeller's influence would nevertheless apply to them. We would regard the greater influence of politically motivated or experienced or charismatic people as a defect in political organization, and take whatever steps we could to eliminate or reduce it. But the second form of the objection would lapse unless we had some other reason, quite independent of any assumption that political influence should be equal, for objecting to a situation in which some people are more politically motivated or trained or charismatic than others.

Consider the common, and wholly justified, complaint that women have too little power of all kinds in most societies. Someone who takes that view might think that social organization is defective unless the average woman has the same influence over affairs (measured in some specified way) as the average man does. But someone else who makes the same complaint might mean something very different: not that men and women should, as a matter of right or ideal, have the same influence on average, but that the smaller influence women now have is the result of a combination of economic injustice, stereotype, and other forms of oppression and prejudice, some of which, perhaps, are so fundamental as to be carried in the community's culture. The difference between these two positions emerges clearly, once again, if we try to imagine a society in which economic, social and cultural discrimination against women has been removed. If the average power of men and women is unequal in such a society - as it might be, in either direction - would that fact, just in itself, count as a defect in social organization?

Once we realize that our most serious worries about inequality of political power can be explained without appealing to equality of influence as an ideal, we are free to consider whether.we have any reason, other than wanting to explain these worries, for accepting that ideal. In my view, we do not. An attractive political community wishes its citizens to engage in politics out of a shared and intense concern for the justice and rightness of the results. It encourages citizens to take pride or shame in the community's success or failure as if it were their own; it aims at that communal goal of political activity. The ideal of equal influence defies that ambition, however. When people are fastidious not to have too much influence, or jealous that they do not have enough, their collective concern is only a matter of show; they continue to think of political power as a discrete resource rather than a collective responsibility.

An attractive society also cherishes a further goal for political activity: that citizens should have as much scope for extending their moral life and experience 
into politics as possible. But people who accept equality of influence as a political constraint cannot treat their political lives as moral agency, because that constraint corrupts the cardinal premise of moral conviction: that only truth counts. Political campaigning under some self-imposed limit of influence would not be moral agency but only a pointless minuet of deference. So the ideal of equality of influence, even if it could be achieved, would be attractive only within a community in which politics was part of economic activity, yet another theater in which each person struggled only to achieve the best life for himself, his family and associates. That ideal is foreign to a genuinely republican form of politics, in which citizens each struggle for the community as a whole.

\section{COMMUNAL COLLECTIVE ACTION}

So the idea that seems so natural to many philosophers, the ideal of equality of political power, is both implausible and artificial. Its defects, fortunately, are also blueprints for an alternative conception of democracy based on a communal rather than a statistical understanding of collective action. But building that conception must start further back, by confronting the problem I acknowledged earlier: that the communal conception seems metaphysically too luxuriant and politically too dangerous to play that role. We must see whether and how we can make sense of genuine communal action without adding dubious collective entities to the furniture of the universe, and whether and how democracy conceived as communal action can be liberal rather than totalitarian.

In fact we can pursue both projects together by exploring the following suggestion: communal action depends not on the ontological priority of community over individual, but on a certain kind of shared attitudes among individuals. Which attitudes? The answer is complex, and requires a set of distinctions. Whenever we act self-consciously, with a sense that what we do is important and can be done well or badly, we implicitly make two assumptions about the unit of action in play. We assume, first, a particular unit of responsibility, by which I mean the person or group to whose credit or discredit, achievement or failure, the action redounds, and, second, a particular unit of judgment, by which I mean the person or group whose convictions about what is right or wrong are the appropriate ones for us to use in making that assessment.

Most of the time the unit of responsibility each person assumes is himself or herself acting as an individual. That remains true in cases of statistical collective action. The American people have poisoned the atmosphere, but most of us each takes responsibility only for his own acts. We have already noticed cases, however, in which this is not so. Many Germans who were not born until after World War II nevertheless feel collective responsibility for what their country did before and during it. The actions were not theirs as individuals, but they believe themselves in some complex way to share in the responsibility for them. Musicians in a flourishing orchestra think of the orchestra's performance in parallel terms: they count themselves to have succeeded only when the orchestra as a whole has. Members of a healthy baseball team take the same attitude towards the success or failure of the team as a whole: each player feels in some way to have failed when his or her team has. In these cases the attitudes of individuals create and presuppose a new unit of 
responsibility: the group. The group, we might say, is the unit that does well or badly, and individuals share in its responsibility derivatively, because they are members of it.

Again, at least in our culture, the normal or usual unit of judgment for all actions is the individual. It is necessary for my self-respect, I think, that I make my own judgments about what kind of life to lead and how to treat others and what counts as good or bad work at my job. I do not mean that I must (or can) make these judgments wholly in private, with no consultation with or influence from other people or my culture as a whole, but rather that I must be satisfied that I am in the end acting on convictions I have formed myself and not just bowing to what others think right for me. But some people, at least sometimes, reject the view that they act as individual units of judgment. They treat themselves as members of a group whose province it is to make moral and ethical judgments on behalf of its members. They believe not just that their own judgments on these matters will inevitably be influenced by their culture, but that they should be, that justice and ethics are at bottom constituted by culture. A German in the nineteen-thirties who accepted a collective unit of judgment could not feel shame for Nazi atrocities, because his nation had endorsed these atrocities as historic triumphs.

We may use these distinctions to restate and expand our ideas about collective action. We distinguish statistical from communal collective action in this way. In statistical collective action, individual actors treat the pertinent unit of agency as individual. When currency traders drive up the price of yen, each acts for himself or herself, and each attends to his own success or failure not that of the group of currency dealers as a whole. In the case of communal collective action, however, individual actors share attitudes that make the pertinent unit of responsibility collective as well as individual. Musicians treat the orchestra as a separate and distinct unit of responsibility - they say the orchestra played well or badly. They share in collective responsibility through what it does, and they are therefore vulnerable to success or failure collectively quite apart from their individual performances. Communal collective action is not a matter of metaphysical but (as we might say) of ethical priority. ${ }^{12}$

We are now in a position to distinguish two forms of communal collective action: integrated and monolithic. In the case of integrated collective action, while the shared attitudes of participants create a collective unit of responsibility, they do not create a collective unit of judgment: the unit of judgment remains thoroughly individual. In the case of monolithic action, on the contrary, both the unit of responsibility and the unit of judgment become collective. Once again, this is a matter of shared attitudes. Compare a good orchestra with a theocratic despotism. In the former, musicians are expected to develop and retain their own sense of musical achievement: their pride in what the orchestra has done is based on their own, self-consciously individual, judgments of musical merit. In a theocratic despotism, on the other hand, anyone who claimed an independent platform of conviction would be a revolutionary, even if his independent convictions endorsed the theocracy. Such a community judges itself.

12. For a more extended account of ethical priority, see my article, "Liberal Community" (1989) 77 Calif. L. Rev. 479. 
So once we reject the majoritarian thesis that democracy is collective action only in the statistical sense, we must choose between two alternative readings of the idea that it is collective in the communal sense. We can treat democracy as a matter of either integrated or monolithic collective action. Of course we must choose the former, and I describe the choice only to show the difference. In the rest of this essay, I shall try to construct an account of democracy as government by the people, understood in the integrated, communal sense, as equals.

\section{DEMOCRACY AS INTEGRATION}

In a genuine democracy, the people govern not statistically but communally. They treat their nation as a collective unit of responsibility, which means that they, as citizens, share derivative responsibility for whatever their government, acting officially, does. But though the people form a distinct unit of responsibility, they do not form a collective unit of judgment. In a communal democracy, each citizen insists that his political convictions are in every important sense his business, that it is his independent responsibility to decide what is required of the nation to do well, and whether or how far it has succeeded. As I suggested earlier, the structural constitution of a democracy conceived in those terms must be different, and more complex, than the structure of a statistical democracy. We construct a statistical democracy by choosing some arrangement of power and function among citizens, officials and institutions that allows political decisions roughly to match the will of the majority. We need more than that for a communal democracy: we need background institutions and assumptions that elicit and nourish the needed pair of democratic attitudes: collective responsibility and individual judgment.

Which institutions and assumptions do create and promote democracy on that conception? Studying other forms of integrated communal action can be helpful, in answering that question, only to a point, because few of these will be examples of democracies. (Though an orchestra, for example, can be organized democratically, few are and good ones are not. Democratically organized football teams would be ineffectual, and probably suicidal.) We do better to reach the political case directly, and I shall use the following interpretive strategy. We begin with a number of pre-interpretive assumptions about what good democracy is like in practice: that the vote is widely dispersed according to the formula one-person one-vote, that freedoms of speech and assembly and demonstration and religion and conscience are recognized and protected as valuable, that no group of citizens is excluded from participating in the community's economy, and so forth. We must see how far these familiar institutions and assumptions can be justified on structural assumptions: that they create and maintain an integrated communal agent, the people, in which individual citizens figure as equal members. I shall organize the discussion around the three main contributions familiar political institutions might be thought to make to that end. They give individual citizens a part in the collective, a stake in it, and independence from it.

\section{A. THE PRINCIPLE OF PARTICIPATION}

In a democracy understood as communal government by equals, each person must be offered a role that allows him to make a difference to the character of 
political decisions, and the force of his role - the magnitude of the difference he can make - must not be structurally fixed or limited by assumptions about his worth or talent or ability. The first part of this principle - that everyone must have a role - holds for any collective unit of agency: no one counts as part of a collective agent unless he is in a position to make a difference to what the collective agent does. I cannot sanely treat myself as a member of the Berlin Orchestra even if the members of that orchestra were willing to call me a member, so long as I continue to have no role in its performances. The principle of participation is democratic only in virtue of its second part, which insists that each member have a role to play consistent with the assumption that he is an equal member. This part of the principle explains why an orchestra is not a democracy, in the ordinary case. The conductor is not chosen by the members; he is imposed on them, and the power he exerts over them, to define and dictate the collective agent's performance, is assigned from outside the community on the justification that he has special talents ordinary members do not. Democracy cannot be like that.

The participation principle is sufficient to explain why we associate democracy with universal or near universal suffrage and single-vote-for-each voting schemes, and with structures of representation that make political offices open in principle to everyone. A scheme of that sort satisfies the principle and no substantial deviation from it would. History, which attaches meanings to structures, plays a part in that judgment. Since electoral schemes that were not based on equal suffrage usually reflected the view that rich people are more worthy to govern than poor ones, or that some races lack the rights or capacities of others, or that one sex is and ought to be subordinate to the other, any contemporary variation from one-person-one-vote must be suspected of bearing a parallel meaning equally offensive to the participation principle. But that is not invariably so, and sometimes history protects rather than condemns an institution that deviates from one-person one-vote. History. explains the composition of the United States Senate, for example, in a noninvidious way. At least in principle other lapses in one-person one-vote might be justified as in-offensive to the participation principle, including, for example, districting arrangements that allow special voting power to groups that have special needs.

The participation principle also explains why the political liberties, like freedom of speech and protest, are part of the idea of democracy. If each citizen is to be given a role in politics that amounts to a genuine chance to make a difference, then, particularly in a large political community, he must be allowed voice as well as vote. A voting scheme that limited the participation of most citizens to an up-or-down vote when the debate was over would neither encourage nor justify the democratic attitude. And selective content-based censorship would violate the second part of the participation principle, which stipulates that people's political power cannot be reduced by regulations that violate equal respect. But I have not fallen back on the idea of equality of influence that I rejected earlier. Democracy, on the communal understanding, requires that individual citizens each be in a position to make a difference, and it also requires that their power to make that difference not be limited, vis a vis the power of others, by structures or regulations that themselves deny equal respect. Those stipulations do not together make up a positive requirement that each citizen either actually have, or even be in a position to have, as much influence over the collective decision as any other, however. They do not aim at 
a state of affairs in which someone will not be able to achieve more influence over his fellow citizens in virtue of the appeal of his cause or personality or arguments or convictions.

\section{B. THE PRINCIPLE OF STAKE}

In a democracy understood as communal, collective decisions must reflect equal concern for the interests of all members. Once again, this principle of stake reflects our understanding of the root idea of communal agency. Membership in a collective unit of responsibility involves reciprocity: a person is not a member of a collective unit sharing success and failure unless he is treated as a member by others, and treating him as a member means accepting that the impact of collective action on his life and interests is as important to the overall success of the action as the impact on the life and interests of any other member. Though even Germans who actively opposed Hitler feel a measure of collective responsibility for his crimes, it would be absurd, even perverse, for German Jews to feel any such sense. So the communal conception of democracy explains an intuition many of us share: that a society in which the majority distributes resources unfairly is undemocratic as well as unjust. The communal conception unites procedural and substantive justice by insisting that democracy means government both by and for the people; under that conception the distinction between those two departments of justice is only superficial. How the community treats its members is part of what decides whether they are members of it, and therefore whether political decisions are made by a collective agent that includes them.

Does the principle of stake make democracy a black hole into which all other political virtues collapse? Statistical conceptions of democracy at least have the merit that they explain our sense that democracy is only one among political ideals, that it is not the same thing as justice, and that a democratic political system can therefore produce unjust results. The communal conception of democracy, just because it dissolves the line between procedural and substantive justice, seems to threaten that apparently valid and useful distinction. We can check the threat, however, and produce a more successful analysis of communal democracy, if we take the principle of stake to require not that a community must have achieved the best or the right understanding of what equal concern actually requires in order to count as a democracy, but only that it must accept the idea of equal concern as an abstract requirement. Its economic, social and legal arrangements must be such as could in the main be justified by some good faith interpretation of what equal concern requires.

Suppose you and I think that utilitarianism is an unsatisfactory account of equal concern, and that utilitarian political decisions are often unjust. We will nevertheless think that a community satisfies the principle of stake if its political decisions match a utilitarian understanding of equal concern, and this understanding is widely held to be the right one by its members, even though we believe many of its actual decisions unjust. In this way we retain the idea that democracy is only one among the political virtues. Nevertheless, there will be a limit to the degree to which a genuine democracy can be unjust. A political system with equal suffrage, in which the majority distributes everything to itself with no concern whatever for the fate of some racial or other minority, will not count as an unjust democracy on the 
communal conception, but as no democracy at all. That is not, I think, an embarrassment to the communal conception, because our pre-interpretive assumptions reject the idea that outcomes are never relevant in deciding whether a regime is democratic.

\section{THE PRINCIPLE OF INDEPENDENCE}

The principle of stake distinguishes communal from merely statistical democracy. A majoritarian tyranny, in which minorities are systematically cheated of their fair share, may nevertheless be a perfect statistical democracy. When we insist that a genuine democracy must treat everyone with equal concern, we take a decisive step towards a deeper form of collective action in which "we the people" is understood to comprise not a majority but everyone acting communally. The third principle - the principle of independence - is necessary to a further distinction: in order that democracy be understood as communal in an integrated rather than a monolithic sense. Citizens of an integrated community must be encouraged to see moral and ethical judgment as their own responsibility rather than the responsibility of the collective unit; otherwise they will form not a democracy but a monolithic tyranny. The principle of independence therefore insists that a democratic government must not dictate what its citizens think about matters of political or moral or ethical judgment, but must, on the contrary, provide circumstances that encourage citizens to arrive at beliefs on these matters through their reflective and finally individual conviction. ${ }^{13}$

As I said earlier, it is undeniable that peoples' personalities are influenced by - at some abstract level they are limited to - what is available in their culture by way of practice, example and vocabulary. And of course we all do and should take an interest in the value of lives that fellow citizens - not just our children and relatives and friends - lead. And of course we should think and reason about morality and the good life together, in conversation rather than in solitary monastic confinement. The principle of independence denies or forbids none of this. Nor does it forbid the community from attempting to change individual citizen's minds through persuasion, that is, through means that enhance rather than corrupt cognitive ability. But the principle declares that democracy, on the right conception, is subverted when the community adopts coercive or hidden or indirect means to shape the

13. In any integrated communal agency, some line must be drawn between the private and the collective, between those matters that are properly matters of collective responsibility and those that must be left for distinct individual decision. In a healthy orchestra, that line is drawn between performance and judgment, as I said. Musicians accept that the orchestra collectively, through its director or conductor, will decide how each should play a particular symphony, and they accept collective responsibility for its performance even when they disagree with the conductor's decisions. Each may think that it, and therefore they, has failed because his taste was bad or his decisions were wrong. But they cannot accept that it is part of the communal life of the orchestra to decide not only how they should play but what they should think of the decision to play that way. If they did, then the orchestra would no longer be an integrated form of a communal agent: it would have become monolithic. Of course the line between an integrated community's collective life and the separate lives of its members reflects other features of its organization, and in every case separate lives will include much more than judgment. It is no part of an orchestra's collective life to decide who its members must marry, for example. But the idea I am emphasizing, that in an integrated community the collective life cannot include moulding the judgments of its individual members as distinct from what they do, has a distinct, near definitional importance, because it sets minimal conditions for any community, of any kind, that aspires to integration rather than to monolith. 
convictions of its citizens. Any collective ambition to dictate individual conviction would undermine communal democracy in one of two ways. If the collective ambition is general and embraces the whole range of individual beliefs and opinions, as it does in a theocratic despotism, then its very existence as an ambition denies the integrated character of the community: it aims at a wholly monolithic community. If the collective ambition is selective and discriminatory - if it aims only to eliminate certain beliefs collectively judged wrong or degrading - then it destroys integration for those citizens who are the objects of reform, because it excludes them from the community altogether. Independence of judgment, that is, is a structural condition of membership in an integrated community. Just as it is preposterous for a German Jew to accept collective responsibility for Nazi atrocities, it is preposterous that I should think of myself as sharing integrated collective responsibility within a group that denies my capacity to judge for myself.

The principle of independence has crucial consequences for the analysis of democracy. It adds, first, to the case we developed under the principle of participation for treating the political liberties as themselves structural to democracy. It insists on a structural place for constitutional guarantees of freedom of speech, association and religion, all of which are necessary to allow and encourage individuals to take responsibility for their own personalities and convictions. The principle of independence has a further consequence that will strike many as more surprising, moreover. It makes some form of liberal tolerance of unpopular sexual and personal morality part of the very conditions of democracy. I must be careful not to suggest that this principle - or indeed any one political principle - is sufficient to dispose of all the issues raised by the question of enforcing morality. A great variety of arguments have been made for illiberal constraints on people's freedom of choice about personal morality and ethics, and liberal counter-arguments must be tailored to the argument they are required to meet. ${ }^{14} \mathrm{My}$ present point, once again, is limited but crucial: not that liberal tolerance is in all circumstances a condition of justice, but that in some form it is a condition of democracy on the communal conception.

Someone might object that the principle of independence has nothing to do with liberal tolerance of sexual and other behavior, because the principle protects freedom of judgment not freedom of action. It is true that laws prohibiting homosexuality, for example, are aimed at conduct not thought. But that distinction is too crude when the individual actor's stake in his own behavior is very much greater than its consequences for others. In other kinds of cases, when a person's conduct does have important effects on other people, an integrated community must distinguish between belief and conduct: it prohibits what it judges to be harmful behavior, but it leaves the actor free to believe and to argue that its decision was wrong and should be reversed. But when the putative harm is mainly to the ethical value of the actor's own life, then the distinction between conduct and judgment loses its point. Having ethical commitments, like having religious beliefs, includes living in their light: a community violates the principle of independence as much by making an individual's personal convictions irrelevant to how he actually leads his life as by forbidding him to have those convictions. That is why

14. For a more general discussion of the complexity of issues raised by the question of liberal tolerance, see Dworkin, "Liberal Community", supra, note 11, and Foundations of Liberal Equality, 1989 Tanner Foundation Lectures forthcoming from University of Utah Press. 
people who object to moralistic legislation say that they want to "make up their own minds," not have the majority do it for them, even when the legislation leaves them free to think what they like so long as they do what it says. These observations might also help to explain why constitutional lawyers use the concept of privacy in explaining why moralism is wrong. They perceive, not that decisions of personal commitments are private in the sense that they are taken while alone and unobserved, but that they are private in the sense opposed to public: that in these areas decisions are too closely fused to judgment to permit them to be matters within the collective life of a communal democracy.

Even those who are drawn to liberalism may distrust the suggestion that it is actually part of the meaning of democracy; it seems illegitimate to decide a fundamental debate in political morality by appealing to a definition. But that is the wrong way to understand this part of my argument. Even if I am right that a communal interpretation of democracy makes liberal tolerance part of what democracy is, people who reject liberalism can reject the communal interpretation in favor of the statistical one. If democracy is statistical - government by a majority - then liberal tolerance must be defended not as part of the meaning democracy but as a matter of justice. So my argument should be construed, not as trying to settle an important issue by the fiat of a definition, but as trying to locate that issue within a larger one by showing how the old debate about enforcing morals connects to a more general debate about how we should understand democratic government. It might seem paradoxical that an explicitly collectivist conception of democracy yields a form of liberalism that has always been thought individualistic. But that sense of paradox itself reflects an inadequate understanding of the varieties and complexity of collectivist understandings of political action. ${ }^{15}$

\section{COMMUNITY AND CONSTITUTION}

Suppose we now accept that the communal conception is the best interpretive account of democracy, particularly in a political community whose constitution restricts majority powers. We can then return to the question with which I began. Do disabling constitutional provisions limit or compromise or offend democracy understood in that way? I have already suggested that once we understand democracy as communal rather than statistical, the approach Ely used to defend some constitutional constraints as democratic can be generalized to defend many others. Ely said (you will remember) that certain expressly disabling constitutional constraints, like restrictions on the power of the majority to abridge free speech, are also functionally structural. They do not limit democracy but are necessary to create it. Ely had the statistical conception of democracy in mind, and he therefore denied that many disabling provisions, including, for example, the due process clause if it were understood to grant homosexuals a right of privacy, could be regarded as structural. He thought that all the disabling constitutional constraints except those

15. We should notice the historical associations between democracy and liberal attitudes about enforcing personal morality. Freedom of conscience was claimed as a defense against the tyranny of monarchs and bishops, and so was part of the initial impulse toward democracy. Self-govemment of the individual was associated with self-government of the people. John Stuart Mill was an ardent democrat, but he distinguished democracy from mob rule, just as we have been distinguishing communal from monolithic collective action. 
that directly or indirectly improve the ability of politics to reveal majority will are anti-democratic.

But suppose we substitute the communal account of democracy for the statistical account Ely assumed. Then many more disabling provisions are at least candidates for the status of structural. I do not mean that once we switch to a communal interpretation of democracy every provision of the Canadian Charter or the United States Constitution, as interpreted by the two Supreme Courts, can be shown to create and protect rather than compromise democracy. The framers of a constitution may aim at limiting as well as creating a communal democracy, and even when they aim only at creating one, they or the Courts who interpret them may misunderstand what a communal democracy requires. I intend not the absurd claim that every constraint on majoritarian power improves democracy, but only that the range of constraints that do improve it is much larger and more varied once we recognize that government by the people is communal not statistical.

\section{A. THE PLAIN PROVISIONS}

We noticed that Ely's analysis would not rescue some of the most prominent parts of the Bill of Rights. These include the First Amendment's guaranty of the free exercise of religion and prohibition of an established church, the provisions of the Fourth and Fifth Amendments which stipulate procedures protecting those accused of crimes, the Eighth Amendment, which forbids cruel and unusual punishments, and the mysterious Ninth Amendment, which holds out the possibility that citizens have other rights government must respect beyond those specifically described in the other amendments. These and other provisions plainly restrict what a majority of voters can achieve, but they do not seem amenable to a structural translation on the statistical conception of democracy, as Ely recognized. But disabling provisions like these might well seem structural on the communal conception of democracy. Freedom of religion is plainly required by the principle of independence, for example. Criminal procedure is much more complicated, but some constraints on what the majority may do to a criminal suspect act to protect people's membership in a community of responsibility as long as possible. The presumption of innocence, from which many of the familiar procedural constraints derive, is a presumption of continued membership. And the Ninth Amendment can be understood as a recognition that individuals have whatever rights are otherwise necessary to protect their position as equal members of an integrated communal agency of government.

Even the disabling provisions Ely recognized as functionally structural are more plausibly understood that way on the communal conception. The statistical model emphasizes the benefits of free speech to the audience, for example, because elections are more likely to indicate the true majority will when people in general are better informed. The communal model allows us also to regard the speaker side of free speech as structural, because that aspect of free speech protects the principle of independence. (It is, after all, the speaker's right to speak not the audience's right to hear that the First Amendment protects directly.) The case for constitutional guarantees against racial discrimination, as a structural requirement of democracy, is even more evidently improved by switching from a statistical to a communal conception. We can imagine systematic racial discrimination that did not affect the political capacities of members of the minority; their relatively poor position as a 
group might be caused not by any lack of education or power or political awareness but entirely because they are outvoted by a majority that self-consciously excludes them from its concern. The communal conception, by making the principle of stake part of democracy, offers a more direct and persuasive account of why systematic discrimination would be undemocratic even in those circumstances.

\section{B. JUDICIAL INTERPRETATION}

My main concern, however, is not with the plain or uncontroversial disabling provisions of a constitution, but with more abstract disabling clauses, like the due process and equal protection clauses of the American Constitution. The great debate whether a constitution is consistent with democracy focuses on those clauses, because different answers produce different views about how the Supreme Court should decide particular cases, as we noticed near the beginning. How is that debate affected when we understand democracy as communal rather than statistical?

Any legal interpretation should aim at a coherent account of the legal order as a whole. ${ }^{16}$ So any interpretation of constitutional law in a democracy must take the fact of democracy into account. We should prefer an interpretation of the due process or equal protection clause that is consistent with democratic principles, as lawyers who urge conservative constitutional decisions insist. But that coin has another side. Since our nations have constitutions with disabling provisions, any interpretation of our democracy must be consistent with the fact that we have rejected unconstrained majoritarianism. So long as we see democracy as statistical, and therefore as unrelentingly majoritarian, these two demands on a successful interpretation of our law cannot both be met. We must settle for awkward compromises, like defiance or historicism or passivism, that deny our legal system integrity at the most fundamental level. When we change to a communal conception of democracy, however, then integrity is once again available. For that interpretation of our democracy permits us to understand disabling constitutional provisions not as compromising democracy but as an important part of the democratic story. We make the best of the legal order as a whole, subordinating neither of its central structuring features to the other, by interpreting disabling clauses as edicts of political and moral principle protecting democracy, not the residue of historical politics or embarrassments to be ignored so far as possible.

I cannot hope to show the implications of this idea for constitutional adjudication in any detail here. I can only suggest, in a general way, how the leading principles of a communal conception of democracy make interpretive democratic sense of a variety of disabling provisions. We have already noticed how the principle of participation supports political liberties. Constitutional guarantees of free speech, for example, are indispensable to allowing people to regard political activity as an extension of moral agency. ${ }^{17}$ The principle of stake shows the good sense in the general approach the American Supreme Court has developed in interpreting the abstract Equal Protection clause. The Court's distinctions between relaxed and strict scrutiny, and between the rational relationship test and the compelling interest test, though awkward and open to improvement, are a response to the requirement that

16. See my book, Law's Empire, supra, note 2.

17. Reference to Part 4, herein. 
the principle of stake imposes on constitutional interpretation. ${ }^{18}$ That principle requires a court to distinguish cases in which majoritarian government has made a good faith attempt to show equal concern for all citizens, a decision no court should disturb, from cases in which a government's decision reflects prejudice or partisanship rather than equal concern, when the courts must protect democracy by protecting those against whom the prejudice runs.

The principle of independence suggests a strategy for assessing the Supreme Court's privacy jurisprudence. Consider the problem that now occupies a large part of the constitutional stage in both Canada and the United States: abortion. Does a woman have a constitutional right to a fair opportunity to terminate her pregnancy if she wishes? The principle of independence comes into play only after another question has been answered. Many people believe that a fetus, from the moment of conception, is a constitutional person, that is, a person entitled to the equal protection of the law stipulated by the Fourteenth Amendment of the American Constitution. If they are right, then women cannot have an unconstrained right to an opportunity for an abortion: if a nation or state must show as much concern for a fetus as for a mother, then it is plainly entitled to deny her an abortion for her own convenience when she knew and accepted the risk that sexual intercourse would make her pregnant. (Indeed there is a strong argument that a state must deny her an opportunity for abortion in such circumstances. ${ }^{19}$ ) So it is a crucial threshold question whether, on the best interpretation of the law as a whole, a fetus is a constitutional person. That is a very different matter from the metaphysical question which theologians and philosophers have debated for many centuries: whether the fetus is a person at all. Perhaps the soundest philosophical theory shows that certain animals are persons. But even so it would not follow - and it seems improbable - that the best interpretation of the American or Canadian constitutions would recognize these animals as constitutional persons, entitled to as much concern as ordinary human beings.

My own view is that a fetus is not a person under American constitutional law from the moment of conception. Nor, I believe, is a fetus a person under the Canadian Charter. But that is not the end of the question whether a woman has a constitutional right to a chance for an abortion, because the community is allowed to protect the existence of beings and things that are not persons entitled to equal concern. Two arguments will be pressed why, even if a fetus is not a constitutional person, a political community is entitled to forbid abortion. The first appeals to the community's interest in the survival and well-being of potential life. If a community is allowed to protect future persons through a conservation policy, for example, why should it not be entitled to protect entities already in existence which, if a natural process is allowed to continue, will almost certainly become human beings within nine months? The second argument recognizes what is undeniable: that a woman's decision about abortion is a profound, personality-shaping decision. The

18. See Laurence H. Tribe, American Constitutional Law, 2nd ed. (Mineola, N.Y.: The Foundation Press, Inc., 1988) 1451-66 (relaxed and strict scrutiny) and 1439-51 (rational relationship and compelling interest tests).

19. In two articles in the New York Review of Books, I argue these claims, and expand on the other arguments of this section, in the context of the Supreme Court's recent decision in Webster v. Reproductive Services. See "The Great Abortion Case", New York Review of Books (June 24, 1989), vol. 36, no. 11 at 49, and "The Future of Abortion", New York Review of Books (September 28, 1989), vol. 36, no. 14 at 47 . 
argument appeals to a community's supposed right to insist that certain moral and ethical standards be met by all its citizens, so that the community can collectively decide what kind of community it is.

But in a democracy understood as communal, the first argument - about the community's common interest in protecting a fetus - must confront the principle of stake. Though a communal democracy may pursue a variety of policies benefiting those who are not its members, it must do so in a way that does not burden some of its members so disproportionately as to deny them its equal concern. An antiabortion law that operates from conception has savage consequences for women, particularly for poor and poorly educated ones, and such laws are genuine and serious obstacles to financial and social equality for women.

The principle of independence is engaged by the second argument, because any supposition that a community has a right to set moral standards for all its citizens flatly contradicts that principle. In a genuine communal democracy, government by the people means government that leaves each person responsible for the development of his or her own ethical and moral personality. It is hardly an argument for the community's itself taking over a particular ethical decision that the issue then involved is a peculiarly grave or deep one; that circumstance would make any violation of the principle of independence more not less serious.

I do not mean these brief and perhaps opaque comments about abortion to constitute a full argument about the constitutionality of anti-abortion statutes and regulations. I mean them only as a contemporary example to help focus our sense of the difference between the two conceptions of democracy I have been discussing. Constitutional lawyers regard the abortion question as an obvious example of the supposed conflict between democratic values and constitutional constraint. Even some lawyers who believe anti-abortion laws to be deeply unfair to women nevertheless believe that it would be undemocratic for a constitution to remove the abortion issue from ordinary politics. They criticize, on that ground, the Supreme Court's 1973 decision in Roe v. Wade, which held that American states lack the power to forbid abortion, except to protect the mother's health, before the third trimester of pregnancy.

Their view is plausible on the statistical conception of democracy. It is much less plausible on the communal conception. We must then decide how far a flat prohibition of abortion undermines women's equal stake and independence as members of a genuine democratic community. Of course even if we decide that flat anti-abortion laws are inconsistent with a communal democracy, for the reasons I tried to suggest or for other reasons, it does not follow that such laws are unconstitutional, because much else beyond political morality is pertinent to constitutional judgments. But considerations of democracy, if they were relevant at all, would then argue for rather than against the Supreme Court's decision in Roe v. Wade. On the communal conception, democracy and constitutional constraint are not antagonists but partners in principle. 